\title{
Concentrate Supplementation for Crossbred Bulls to Increase Profitability of Smallholder Fattening Operations in East Java, Indonesia
}

\author{
Ratnawati $\mathrm{D}^{1}$, Cowley $\mathrm{F}^{2,3}$, Mayberry $\mathrm{D}^{4}$, Pamungkas $\mathrm{D}^{1}$, Poppi $\mathrm{D}^{2}$ \\ ${ }^{1}$ Loka Penelitian Sapi Potong, Jl. Pahlawan No. 2 Grati, Pasuruan 67184, Jawa Timur, Indonesia \\ ${ }^{2}$ School of Agriculture and Food Sciences, University of Queensland, Gatton, Queensland, Australia \\ ${ }^{3}$ School of Environmental and Rural Science, University of New England, Armidale, New South Wales, Australia \\ ${ }^{4}$ CSIRO Ecosystem Sciences, Dutton Park, Queensland, Australia \\ E-mail:dian_sapo@yahoo.co.id
}

(Diterima 16 Januari 2015; direvisi 23 Maret 2015; disetujui 25 Maret 2015)

\begin{abstract}
ABSTRAK
Ratnawati D, Cowley F, Mayberry D, Pamungkas D, Poppi D. 2015. Penambahan konsentrat pada ransum sapi jantan persilangan untuk meningkatkan keuntungan peternak sapi penggemukkan di Jawa Timur, Indonesia. JITV 20(1): 42-48. DOI: http://dx.doi.org/10.14334/jitv.v20i1.1115

Tingkat pertumbuhan sapi pada system penggemukkan oleh peternak skala kecil secara umum masih rendah karena kebutuhan nutrisi kurang tercukupi. Penelitian ini bertujuan untuk membandingkan pertumbuhan sapi dan keuntungan peternak antara sapi jantan dengan pakan tradisional dan sapi jantan dengan pakan tambahan (suplemen) berupa konsentrat berkualitas tinggi. Penelitian ini dilakukan di dua lokasi di Jawa Timur yaitu Probolinggo dan Lamongan dengan menggunakan sapi jantan persilangan PO-Bos taurus berumur 1,5-2 tahun dari yang dibedakan menjadi 2 kelompok perlakuan, yaitu kelompok kontrol dan intervensi. Peternak pada kelompok intervensi, sapi jantan diberi pakan suplemen berupa campuran: onggok, kopra dan bungkil inti sawit. Peternak memberikan suplemen sebanyak $4 \mathrm{~kg} /$ ekor selama 161 hari atau sampai terjual. Managemen pakan pada kelompok kontrol adalah tetap (pola peternak). Umumnya peternak menggunakan hijauan lokal dan hasil samping pertanian sebagai pakan ternak, tanpa adanya suplementasi. Biaya pakan harian dan harga per $1 \mathrm{~kg}$ pertambahan bobot badan sapi lebih tinggi pada kelompok intervensi (Rp. 8.827 dan Rp. 11.990) daripada kelompok kontrol (Rp. 2.606 dan Rp. 5.543). Namun demikian, pertambahan bobot badan harian sapi jantan kelompok intervensi $(0,82 \mathrm{~kg} / \mathrm{hari})$ lebih tinggi dibandingkan dengan kelompok kontrol $(0,52 \mathrm{~kg} / \mathrm{hari})$, sehingga menghasilkan keuntungan yang lebih besar. Pendapatan harian dikurangi dengan biaya pakan pada peternak kelompok intervensi (Rp. 24.182/hari) lebih tinggi dibandingkan dengan kelompok kontrol (Rp. 5.774/hari). Dapat disimpulkan bahwa meskipun terdapat biaya tambahan untuk memberikan pakan berkualitas tinggi, namun dengan tingkat pertumbuhan sapi jantan yang tinggi menghasilkan keuntungan lebih besar pada peternak.
\end{abstract}

Kata Kunci: Pakan, Penggemukkan, Sapi Potong, Suplemen, Konsentrat

\section{ABSTRACT}

Ratnawati D, Cowley F, Mayberry D, Pamungkas D, Poppi D. 2015. Concentrate supplementation for crossbred bulls to increase profitability of smallholder fattening operations in East Java, Indonesia. JITV 20(1): 42-48. DOI: http://dx.doi.org/10.14334/jitv.v20i1.1115

Growth rates of bulls in Indonesia raised in smallholder fattening systems are generally low due to inadequate nutrition. This study compared bull growth and farmer profit between two feeding management systems, namely traditional feeding (as control) and intervention feeding by supplementation with a high quality concentrate. Bos taurus-Ongole cross bred bulls $(\mathrm{n}=46)$ aged 1.5-2 years, owned by smallholder farmers, from two villages in East Java were used in this study. The bulls were divided into two treatment groups; control and intervention. Farmers in the intervention group were provided with a concentrate containing onggok, copra and palm kernel cake. Farmers were instructed to feed $4 \mathrm{~kg} \mathrm{DM}$ of concentrate/bull/day in addition to their existing roughage diet for 161 days or until sold. No changes were made to the feeding or management of the bulls in the control group. Mostly control group farmers used local forages and agricultural by product as a feed, without any supplementation. The daily feed cost and the cost of $1 \mathrm{~kg}$ of liveweight gain was higher in the intervention group (IDR 8827 and IDR 11990 , respectively) than that of the control group (IDR 2606 and IDR 5543, respectively). Moreover, the average daily gain of bulls in the intervention group $(0.82 \mathrm{~kg} / \mathrm{bull} / \mathrm{day})$ was higher than that of bulls in the control group $(0.52 \mathrm{~kg} / \mathrm{bull} / \mathrm{day})$, resulting in a greater profit for the fattening period. Daily income minus feed costs was higher for farmers in the intervention group (IDR 24182/day), compared to farmers in the control group (IDR 15774/day). It is concluded that although there were additional costs for feeding high-quality feeds, but higher growth rates of bulls resulted in greater profits for smallholder farmers.

Key Words: Feed, Fattening, Beef Cattle, Supplement, Concentrate 


\section{INTRODUCTION}

Beef cattle fattening by smallholders is an important farming sector in Indonesia. Traditionally, this is a low input system, utilising locally available forages without any feed supplementation (Abutani et al. 2010). Typically, farmers use locally-sourced forages and agricultural by-products as feeds, without any supplementation. Fattening duration is up to 1 year. The economics of a smallholder fattening enterprise depend on several considerations, one of which is the cost of feeding. It has been estimated that approximately $60 \%$ of the cost of production in beef cattle is feed (Syukur \& Afandi 2009).

Previous research has demonstrated that average daily liveweight gain (ADG) of Ongole, Brahman and European-cross bulls in East Java villages (Pasuruan, Probolinggo and Malang district), Indonesia were substantially below the genetic potential for these breeds (Pamungkas et al. 2012; Pamungkas et al. 2013a; Pamungkas et al. 2013b). This was associated with the low quality forage-based diet, which relied on feeds such as native grass, rice straw and a very small amount of concentrates. Currently, smallholder farmers try to maximise profit by minimising costs, including feed (Priyanti et al. 2012b). However this strategy leads to low ADG, and consequently, low gross daily revenue.

The use of purchased supplements can significantly reduce the time taken for cattle to reach a liveweight target (Winter \& Doyle 2008). Concentrate supplementation can improve diets based on low quality forages (for example: rice straw) through improving metabolisable protein and energy (Anggraeny \& Umiyasih 2004). The expansion of cassava and palm oil plantations in Indonesia offers alternative sources of animal feed such as plantation waste and processing byproducts. By-products such as onggok (cassava by product) and palm kernel cake (PKC) can supply high concentrations of energy and protein. However, they must be purchased at a cost, for example the current price of onggok, PKC and copra is 1500,1250 and 1800 $\mathrm{IDR} / \mathrm{kg}$, respectively. If the value of the additional liveweight gain exceeds the additional feed costs, then the use of concentrate will increase the farmer's income. Limited disposable income means the choice of supplement must be made carefully to provide essential nutrients at minimum outlay (Winter \& Doyle 2008).
It is hypothesised that feeding a high quality concentrate supplement that maximises ADG in a leastcost fashion will increase the profitability of smallholder fattening enterprises in Indonesian villages when compared to traditional feeding strategies.

\section{MATERIALS AND METHODS}

\section{Animals and experimental design}

The study was conducted on-farm in two village sites of East Java Province (Probolinggo and Lamongan) during the period of April-October 2013 (161 days) or until sold. A total of forty-six bulls initially (290 \pm 8.7 (s.e.m.) kg liveweight, body condition score (BCS; $1-5$ scale) 3.1 \pm 0.03 and 1.5-2.3 years old) were used in the study. All bulls at each site were Bos taurus-Ongole crossbred. Bulls were allocated to one of two treatments (control or intervention) based on liveweight and farmer. No changes were made to the feeding or management practices of bulls in the control group $(n=23)$. Bulls in the intervention group $(n=23)$ were provided with $4 \mathrm{~kg}$ dry matter (DM) concentrate/bull/day in additional to their normal daily ration. No other interventions were made to the management or feeding practices of these bulls. The distribution of bulls and farmers across treatments and sites is shown in Table 1.

\section{Diets and feeding}

The concentrate provided to bulls in the intervention group was a mix of onggok (50\%, DM-basis), copra (25\%, DM-basis) and PKC (25\%, DM-basis). Ingredients were purchased from local feed traders, and mixed at the Beef Cattle Research Institute in Grati, East Java. The ration was formulated using the Large Ruminant Nutrition System (LRNS) version 1.0.17, which is based on the Cornell Net Carbohydrate and Protein System (Fox et al. 2004), and was evaluated for feeding Indonesian Ongole cattle (Mayberry et al. 2014). According to LRNS formulation, the concentrate would provide 10.6 MJ metabolisable energy (ME) and $117 \mathrm{~g}$ crude protein $(\mathrm{CP})$ per kg dry matter (DM). The cost of the concentrate, based on purchase costs from traders, was IDR 1661/kg DM.

Table 1. Number of bulls and farmers involved in the study

\begin{tabular}{lcccccc}
\hline \hline & \multicolumn{2}{c}{ Probolinggo site } & & \multicolumn{2}{c}{ Lamongan site } \\
\cline { 2 - 3 } \cline { 5 - 6 } & Control group & Intervention group & & Control group & Intervention group \\
\hline Number of bulls & 8 & 8 & & 15 & 15 \\
Number of farmers & 6 & 8 & & 15 & 13 \\
\hline
\end{tabular}


Farmers in the Intervention group were provided with the concentrate and a standardized bucket. The bucket could contain $4 \mathrm{~kg}$ of concentrate. Farmers were given instructions to feed one full bucket of concentrate to their fattening bulls, in addition to their regular daily ration, each day over the experimental period (161 days). This was equivalent to $13.8 \mathrm{~g} \quad \mathrm{DM} / \mathrm{kg}$ liveweight/day for the average bull at the beginning of the experiment. The concentrate was delivered to the farmers each month, at the regular monitoring visit.

\section{Measurements, analyses and calculations}

Each month, a list of every feed offered to each bull on the monthly monitoring day was recorded, and a sample taken for proximate analysis. Feed samples were dried, bulked for all farmers for the experimental period, and analysed for DM, organic matter, $\mathrm{CP}$ and ash-free neutral detergent fibre (NDF) contents. Weight of each feed offered to the bulls was measured monthly for ten farmers at each site, split equally between treatments $(\mathrm{n}=20)$.

Feed samples were dried at $60^{\circ} \mathrm{C}$ for 48 hours to determine DM. Dried samples of each feed were ground to pass through a $1 \mathrm{~mm}$ screen in a Retsch GmBH 5657 HAAN mill. Organic matter was determined by combusting samples at $600^{\circ} \mathrm{C}$ for 3 hours in a NEY M525 Series II furnace (AOAC 1984). Total N was analysed using the Kjeldahl technique (AOAC 1984). Ash-free NDF was measured according to the technique described by Goering \& Van Soest (1970).

Liveweight and height of bulls were measured at the start and end of the experiment or at sale, if the bull was sold before the end of the experiment. This was used to calculate the average daily gain (ADG). Girth and BCS (1-5 scale) were measured monthly and at sale. At sale, the date, sale price, and sale weight of bulls were recorded. Data on sale prices and weights were used to determine an average sale price per kilogram liveweight for each treatment group. This average price per kilogram liveweight was applied to the calculated ADG from all bulls in the treatment group, whether sold or not, to determine the average value (IDR/ $\mathrm{kg}$ ) of the liveweight gain per day.

The cost of any feeds purchased by the farmer was recorded and used to calculate daily feed cost (on a fresh basis). Daily feed cost was calculated using the purchase cost of any feeds bought by the farmers plus the purchase cost of the intervention concentrate ingredients from traders (for the Intervention group only). Since forages were obtained free of charge by all farmers, there was no cost attributed to forage feeds. The ADG and daily feed cost was used to calculate feed cost/ kg liveweight gain, which is the feed expenditure required to grow each kilogram of liveweight.
Income over feed cost (IOFC) was calculated by the method of Bailey et al. (2009), IOFC $=($ Sale price $/ \mathrm{kg}$ liveweight at sale $\mathrm{x}$ average daily liveweight gain) daily feed cost, where sale price/ $\mathrm{kg}$ liveweight was an average value for each treatment group, determined as above.

Differences in liveweight, feed offered, daily feed costs and IOFC between the two groups were compared by Student's t-test in Minitab 16.1.1 (Minitab Inc., State College, PA, USA).

All procedures were reviewed and approved by the University of Queensland Animal Ethics Committee in accordance with the Australian Code of Practice for the Care and Use of Animals for Scientific Purposes.

\section{RESULTS AND DISCUSSION}

\section{Diet and supplementation}

Both groups of farmers fed their bulls a range of different feeds, which included: agricultural byproducts (rice straw, corn stover), locally obtained forages (native grass; elephant grass (Pennisetum purpureum); gliricidia (Gliricidia sepium); leucaena (Leucaena leucocephela); sesbania (Sesbania grandiflora) and rice bran. Not all farmers used all feed types. Of these feeds, only rice bran was purchased - all others were obtained without purchase. The average quantity of feed offered to the bulls was shown in Table 2 .

Intervention farmers offered their bulls the same total amount of non-intervention feeds as did the Control group farmers (Table 2). There was no difference between Intervention and Control groups in the quantity of each feed offered, except for corn stover (Table 2). Total quantity of corn stover in Intervention diets was higher than Control diets $(\mathrm{P}<0.05)$ (Table 2). However, the total feed offered to Intervention bulls was higher (12.20 kg DM/bull/day) than control bulls (8.33 kg DM/bull/day) (Table 2). This difference was due to the additional feed (intervention concentrate) offered to the Intervention bulls.

The composition of feeds offered to the village bulls during the experimental period is shown in Table 3.The intervention concentrate was responsible for significant increases in total DM, organic matter, crude protein and NDF offered to the Intervention bulls. Of the intervention concentrate ingredients, PKC and copra had a high CP concentration. The additional microbial crude protein which would have resulted from the higher $\mathrm{CP}$ concentration would have improved the digestibility of the forage basal diet, enabling additional voluntary feed intake. Meanwhile, onggok was high in soluble carbohydrate concentration and low in crude protein concentration. Those feeds can be combined as 
a formulated feed, balanced for energy and protein to meet the nutrient requirements for growth. This combination gave a better response in liveweight gain than does green feed as a single feed. It will support a high growth rate in the bulls, so that the profit of the farmers was higher (Umiyasih \& Antari 2011).

Refusals were not measured, but on average Control bulls were offered feed at a rate of $2.54 \%$ of their liveweight, and Intervention bulls were offered feed at a rate of $3.42 \%$ of their liveweight (DM-basis). This is likely approaching or exceeding ad libitum feed on offer, for the respective diets.

\section{Liveweight gain and economic analysis}

Table 4 shows an economic analysis of this fattening system. Profitability and economic viability of fattening operation systems would be the main goal for smallholder farmers. Fattening period was deemed to be the time between the start of the experiment and the sale of the bull, or if the bull was not sold, the end of the experimental period (161 days). Thirty-two bulls were sold before the end of the 161 day experimental period. The average fattening period duration was $132 \pm 6$ days. There was no significant difference in the sale price

Table 2.Average quantity of feed offered to Bos taurus-Ongole cross bred bulls based on treatments

\begin{tabular}{lccc}
\hline \hline Feed offered to bulls(kg DM/bull/day) & Control & Intervention & s.e.m. \\
\hline Rice straw & 2.4 & 2.1 & 0.38 \\
Native grass & 2.3 & 2.3 & 0.19 \\
Elephant grass & 1.5 & 1.6 & 0.15 \\
Corn stover & $0.6^{\mathrm{a}}$ & $1.2^{\mathrm{b}}$ & 0.13 \\
Rice bran & 1.1 & 1.0 & 0.09 \\
Gliricidia & 0.2 & 0.2 & 0.08 \\
Leucaena & 0.2 & 0.2 & 0.08 \\
Sesbania & 0.1 & 0.0 & 0.02 \\
Intervention concentrate & $0^{\mathrm{a}}$ & $3.9^{\mathrm{b}}$ & 0.19 \\
Total non-intervention feeds & 8.33 & 8.65 & 0.30 \\
Total feed offered & $8.33^{\mathrm{a}}$ & $12.20^{\mathrm{b}}$ & 0.35 \\
\hline
\end{tabular}

Values within rows followed by different letters are significantly different at $\mathrm{P} \leq 0.05$

Table 3. Average chemical composition of feeds offered to Bos taurus-Ongole cross bred bulls in Probolinggo and Lamongan, East Java

\begin{tabular}{lcccc}
\hline \hline Feed type & Dry matter $(\mathrm{g} / \mathrm{kg})$ & Ash $(\mathrm{g} / \mathrm{kg} \mathrm{DM})$ & Crude protein $(\mathrm{g} / \mathrm{kg} \mathrm{DM})$ & Ash-free NDF $(\mathrm{g} / \mathrm{kg}$ DM) \\
\hline Intervention concentrate & 910 & 147 & 123 & 530 \\
Corn stover & 260 & 71 & 81 & 677 \\
Elephant grass & 165 & 154 & 42 & 647 \\
Gliricidia & 217 & 111 & 267 & 368 \\
Leucaena & 338 & 69 & 288 & 351 \\
Native grass & 202 & 146 & 107 & 625 \\
Rice bran & 849 & 127 & 105 & 335 \\
Rice straw & 372 & 103 & 79 & 729 \\
Sesbania & 224 & 106 & 255 & 260 \\
\hline
\end{tabular}


Table 4. Growth, feed costs and profitability of Bos taurus-Ongole cross bred bulls fed their usual ration (Control), or their usual ration plus a concentrate containing onggok, copra and palm kernel cake at $4 \mathrm{~kg} \mathrm{DM} / \mathrm{bull} /$ day (Intervention)

\begin{tabular}{lccc}
\hline \hline & Control & Intervention & s.e.m. \\
\hline Average daily liveweight gain (kg/day)* & $0.52^{\mathrm{a}}$ & $0.89^{\mathrm{b}}$ & 0.06 \\
Daily cash feed cost (IDR/bull/day) & $2606^{\mathrm{a}}$ & $8827^{\mathrm{b}}$ & 589 \\
Feed cost per kg liveweight gain (IDR/kg liveweight gain) & $5543^{\mathrm{a}}$ & $11990^{\mathrm{b}}$ & 1159 \\
Bull sale price (IDR/kg liveweight) & $35696^{\mathrm{a}}$ & $37232^{\mathrm{a}}$ & 627 \\
Income over feed cost (IDR/day) & $15774^{\mathrm{a}}$ & $24182^{\mathrm{b}}$ & 1936 \\
\hline
\end{tabular}

* Average daily liveweight gain over the duration of the experiment (April-October 2013), or until sale (if sold before end of experiment) Values within rows followed by different letters are significantly different at $\mathrm{P} \leq 0.05$

per kg liveweight for the two groups (Table 4). Bulls in the Intervention group gained liveweight nearly twice as fast as bulls in the Control group that had no changes made to their feeding $(\mathrm{P}<0.05$; Table 4$)$. The average daily feed cost of the Intervention group, consisting of farmer-purchased feed expenditure and the price of the intervention concentrate, was higher $(\mathrm{P}<0.05$; Table 4$)$ than the Control group, which consisted of farmerpurchased feeds only. Feeding the formulated intervention supplement caused an increase in the feed cost to produce each kilogram of liveweight $(\mathrm{P}>0.05$; Table 4), and as a consequence, reduced the profit per kilogram of liveweight gain. The cost of liveweight gain in the Intervention group was lower than that previously reported by Cruz de Carvalho et al. (2010) for Simmental-Ongole crossbred cattle fed a 55\% concentrate diet in a feedlot system (IDR 16947/kg), most likely because of the collection of forages free of charge. However, because of the substantial differences between the two treatments in ADG and the period of time to reach a specified weight, using cost of gain as an indicator of profitability is insufficient (Allison \& Baird 1974). Income over feed cost instead considers the total value of liveweight increased in the fattening period: where gross returns per day are sufficiently high, these can more than compensate for the increased cost of gain. Here, IOFC for intervention bulls was higher $(\mathrm{P}<0.05)$ than for control bulls (Table 4$)$. The additional liveweight gain from the Intervention supplement increased those farmers' IOFC for the fattening period by IDR 8408 per day, making the intervention diet more profitable for the fattening period.

Supplementing fattening bulls with a high-quality concentrate is a more profitable feeding strategy than the low-input, traditional feeding strategies used by smallholders in East Java villages. Feeding bulls a better quality diet can improve farmer income in two ways: 1) for a given fattening period, a single bull will have a heavier sale weight, and 2) the bull will reach a specified weight faster, and the farmer then can fatten more bulls each year. A supplemental feeding strategy such as the Intervention tested in this experiment will be successful if the additional revenue from the increased liveweight of beef produced exceeds the extra costs incurred from feeding the higher quality feed. For smallholder farmers, the dual constraints of capital and available labour limit the number of cattle that can be reared at one time (Roessali et al. 2011). Therefore, the best option for smallholder farmers to increase their income from beef fattening enterprises lies in increasing the rate of liveweight gain of their existing cattle.

There are differences between the fattening practices of smallholder farmers and those of commercial feedlots. The quantity and quality of the concentrates given to bulls would be greater under commercial feedlot feeding practice. Whereas commercial feedlots use a 120 day fattening period, smallholder farmers feed for longer, often only selling when the price is high, or a need for cash arises in the family. In this paper, bulls were monitored for a maximum of 161 days fattening. The average total fattening period for bulls from purchase to sale was not recorded.

The ADG of Bos taurus-Ongole cross bred bulls raised in villages and fed the intervention concentrate was substantially higher than that recorded in East Java villages by other authors (Table 4). It was reported that the ADG of smallholder Simmental- and LimousinOngole cross cattle in villages in Malang and Probolinggo ranged from $0.30-0.50 \mathrm{~kg} /$ day (Aryogi et al. 2005; Pamungkas et al. 2012; Priyanti et al. 2012b). The ADG of the Control group was at the upper end of the range reported by those authors (Table 4).Previous research showed that the ADG of many breeds of cattle fed $100 \%$ PKC and PKC mixed diets were in the range of $0.338-0.830 \mathrm{~kg} /$ day (Chin 2012).

The daily feed cost of village diets in this experiment includes the purchase of the supplied concentrate as well as the cost of any feeds purchased by the farmer, specifically rice bran. It does not include the value of labour or transport used in obtaining feeds, 
nor the value of feeds obtained free of charge. For this reason, Control group farmers who did not purchase feed had no monetary costs outlaid in the feeding of their bulls. An estimate of labour costs would vary depending on several factors, such as family member providing labour, and available opportunities for other employment of that person. Therefore, the true costs of those feeds harvested free of charge are difficult to estimate. However, any estimate of those costs applied to this data would increase the daily feed costs of cattle in both groups. As there was no difference between groups in the amounts of non-intervention feeds offered to bulls (Table 2), an estimate of the associated labour costs is unlikely to affect the results of the relative profitability of the two feeding strategies. Intake and refusals were not recorded in this experiment, however it is likely that that some substitution of the concentrate for the non-intervention feeds would occur, reducing the amount of forage required. Although we did not observe any reduction in the amount of nonintervention feeds offered to intervention bulls, it is possible that if farmers continued feeding the intervention concentrate, they would eventually reduce the amount of other feeds offered, and the time spent gathering those feeds.

Priyanti et al. (2012b) observed that smallholder fattening operations in East Java only rarely purchase feed supplements. In this experiment, only one farmer at the Probolinggo site purchased feed (rice bran) for their fattening operation. However, the purchase of rice bran as a supplement was near universal among farmers of both treatment groups at the Lamongan site. While rice bran has a lower nutritive value than the formulated concentrate offered to the intervention bulls, its purchase price (IDR 2356/kg DM) was higher than the cost of the intervention concentrate (IDR 1661/kg DM). Previous surveys of fattening enterprises in the same areas found that smallholder Euro-cross fattening operations expend IDR 4000-6000 per day on feed (Priyanti et al. 2012b), although much of this expenditure is on crop residues and forages, rather than high quality concentrates (Priyanti et al. 2012a). This suggests that the economics of smallholder fattening operations may permit the use of purchased supplements. By formulating a concentrate with a mix of ingredients (in this case, onggok, PKC and copra), it is possible to mix a ration that was balanced for energy and protein content. Using a mix of ingredients also permits the formulation of a least-cost ration, where the inclusion rate of an expensive ingredient can be reduced and substituted with less expensive ingredients. The relationship between nutritive value and price of concentrates and by-products in Indonesia requires further investigation.
The most cost-effective formulation for a supplement will depend on the ingredient availability and price and the capacity of the farmer to purchase using their disposable income. The intervention fattening strategy tested here does have greater input costs, and requires that the farmer have adequate disposable income to purchase feed before the sale of the bull returns the profit to the enterprise. Alternatively, a source of micro-credit that permits farmers to leverage immediate liveweight gain for a future sale against the cost of concentrates may provide the opportunity for smallholder fattening enterprises to access high quality feed supplements.

\section{CONCLUSION}

Bulls supplemented with high-quality, locally available concentrates have higher growth rates than bulls fed a traditional village diet. Although feeding high-quality concentrates increases daily feed costs and the cost of liveweight gain, however the increased rate of liveweight gain resulted in a higher income for smallholder farmers.

\section{ACKNOWLEDGMENTS}

Our gratitude goes to ACIAR for funding this research and all the team of ACIAR project LPS/2008/038, as well as the village farmers, for their cooperation. Simon Quigley was instrumental in the original design of the experiment.

\section{REFERENCES}

Abutani SA, Rahim S, Noverma. 2010. Respon pemberian "blok suplemen" berbasis bahan lokal terhadap pertambahan bobot sapi Bali. J Sain Peternakan Indones. 5:65-69.

Allison JR, Baird DM. 1974. Least-cost livestock production rations. Southern J Agric Econ. 12:41-45.

Anggraeny YN, Umiyasih U. 2004. Strategi pemberian pakan berbahan biomas lokal pada peternakan sapi potong komersial: Studi perbaikan pakan pada usaha penggemukan. Mathius IW, Bahri S, Tarmudji, Prasetyo LH, Triwulanningsih E, Tiesnamurti B, Sendow I, Suhardono, penyunting. Prosiding Seminar Nasional Teknologi Peternakan dan Veteriner. Bogor (Indones): Pusat Penelitian dan Pengembangan Peternakan. hlm. 72-77.

[AOAC] Association of Official Analytical Chemists. 1984. Official methods of analysis. 14th ed. Washington DC (US): Association of Official Analytical Chemists. 
Aryogi, Sumadi, Hardjosubroto W. 2005. Performans sapi silangan Peranakan Ongole di Dataran Rendah (study kasus di kecamatan kota anyar, kabupaten Probolinggo Jawa Timur. Mathius IW, Bahri S, Tarmudji, Prasetyo LH, Triwulanningsih E, Tiesnamurti B, Sendow I, Suhardono, penyunting. Prosiding Seminar Nasional Teknologi Peternakan dan Veteriner. Bogor (Indones): Pusat Penelitian dan Pengembangan Peternakan. hlm. 98-104.

Bailey K, Beck T, Cowan E, Ishler V. 2009. Dairy riskmanagement education: Managing income over feed costs. In: Agricultural communications and marketing. Pennsylvania (US): The Pennsylvania State University.

Chin FY. 2012. Palm kernel cake (PKC) as a supplement for fattening and dairy cattle in Malaysia. Department of Veterinary Services. Kuala Lumpur, Malaysia. [diakses pada 21 Juli 2013]. www.fao.org/ag/AGP/agpc/doc/ proceedings/manado/chap $25 . \mathrm{htm}$

Carvalho CD, Soeparno MD, Ngadiyono N. 2010 Pertumbuhan dan produksi karkas sapi Peranakan Ongole dan Simmental Peranakan Ongole jantan yang dipelihara secara feedlot. Buletin Peternakan._34:38-46.

Fox DG, Tedeschi LO, Tylutki TP, Russell JB, Van Amburgh ME, Chase LE, Pell AN, Overton TR. 2004. The Cornell net carbohydrate and protein system model for evaluating herd nutrition and nutrient excretion. Anim Feed Sci Tech. 112:29-78.

Goering H, Van Soest P. 1970. Forage fibre analyses (apparatus, reagents, procedures and some applications). Handbook no. 379. Washington DC (US): United State Department of Agriculture.

Mayberry DE, Syahniar TM, Antari R, Ningrum GP, Marsetyo, Pamungkas D, Poppi DP. 2014. Predicting feed intake and liveweight gain of Ongole cattle in Indonesia. Anim Prod Sci. 54:2089-2096.

Pamungkas D, Antari R, Mayberry DE, Poppi DP. 2012. A growth comparison of Ongole and European cross cattle kept by smallholder farmers in Indonesia. Koonawootrittriron S, Suwanasopee T, Jattawa D, Boonyanuwat K, Skunmun P, editors. Proceedings of the 15th AAAP Animal Science Congress. Bangkok (Thailand). p. 1-4.
Pamungkas D, Cahyadi F, Indrakusuma D, Jazila I, Mayberry DE, Poppi DP. 2013a. Growth of Brahman, Ongole and crossbred bulls kept by smallholder farmers in Indonesia. Lyons M, Broad K, Charmley E, McGrath T, Quirk M, Watson I, editors. Proceeding of Northern Beef Research. Cairns (Australia). p. 179.

Pamungkas D, Cahyadi F, Indrakusuma D, Mayberry DE, Poppi DP. 2013b. Growth of Ongole, Brahman and crossbred bulls under village conditions in East Java, Indonesia. Susilawati T, Radiati LE, Widodo E, Nugroho BA, Orskov ER, Hsia LC, Bottema CDK, Alimon AR, Muladno, Priyanti A, Lapian H, editors. Animal Production International Conferences. Malang (Indones): Brawijaya University. p. 45.

Priyanti A, Hanifah VW, Mahendri IGAP, Cahyadi F, Cramb RA. 2012a. Small-scale beef cattle production in East Java, Indonesia. Pannell D, Polyakov M, editors. Proceeding of Australia Agricultural Research Economy and Social. Fremantle (Australia). p. 1-22.

Priyanti A, Mahendri IGAP, Cahyadi F, Cramb RA. 2012b. Income over feed cost for small-to medium-scale beef cattle fattening operations in East Java. J Indones Trop Anim Ag. 37:195-201.

Roessali W, Masyhuri S, Nurtini, Darwanto DH. 2011. Factors influencing farmers' decision to increase beef cattle business scale in Central Java province. J Indones Trop Anim Ag. 36:27-35.

Syukur SH, Afandi. 2009. Perbedaan waktu pemberian pakan pada sapi jantan lokal terhadap income over feed cost. J Agroland. 16:72-77.

Umiyasih U, Antari R. 2011. Penggunaan bungkil inti sawit dan kopra dan pakan penguat sapi betina berbasis limbah singkong untuk pencapaian bobot badan estrus pertama $>225 \mathrm{~kg}$ pada umur 15 bulan. Prasetyo $\mathrm{LH}$, Damayanti R, Iskandar S, Herawati T, Priyanto D, Puastuti W, Anggraeni A, Tarigan S, Wardhana AH, Dharmayanti NLPI, penyunting. Prosiding Seminar Nasional Teknologi Peternakan dan Veteriner. Bogor (Indones): Pusat Penelitian dan Pengembangan Peternakan. hlm. 192-199.

Winter WH, Doyle PT. 2008. Increased profitability and social outcomes from livestock in smallholder croplivestock systems in developing countries: The ACIAR experience. Aust J Exp Agr. 48:799-805. 